\title{
Pathological Manifestation and Restoration Procedures Analysis of the Historic Building, located in Belém-PA
}

\author{
Catarina de Nazaré Pereira Pinheiro, Adriene Rodrigues Barbosa.
}

\begin{abstract}
The city of Belém, capital of the Brazilian state of Pará, a four hundred years old city, is considered rich with history and cultural diversity. Amongst its historical constructions, the Library “Arquivo Público” - Public Archives stands out for its great importance, not only for its own history and architecture, but also for keeping very relevant documents in its collection. Among the archives, the oldest document is dated from 1649, close to the year of the city's foundation. However, until the beginning of 2014, the building was in a dreadful preservation state. Aiming the conservation of the city's historic and cultural heritage, the renovation of the building was initiated, focusing especially on the restoration of the original architectural pieces, preserving the artistic heritage of the construction. This paper aims to analyze the pathologies found on site and evaluate the restoration process of this historical building, to verify the repair procedures made and to present the results of the construction work.
\end{abstract}

Keywords: Pathologies; Restoration; Construction Repair; Building Maintenance; HistoricHeritage; Structural Rehabilitation

\section{INTRODUCTION}

According to [9], cultural heritage can be understood as an agglomerate of cultural assets that refer to the collective memory of a certain group and it may include aspects such as architectural, documental and gastronomic. [5] states that, even though the notion of historical heritage is often associated with a frozen image of the past, it is a living memory that must be preserved, aiming to protect all of its history and the path trod by the society it refers to.

In this context, the collection the Library Arquivo Público appears as an important source of information concerning the cultural heritage of the amazon region. According to [10], the building constructed in 1858 to be the states commercial bank (Fig. 1), began the keeping of historical documents of the Pan-Amazon in 1894, being officialized as library and public archive in the year of 1901(Fig. 2). The current collection contains more than four million documents, dated from 1649 to 1986 , comprehending three Brazilian historical periods: colonial, imperial and republican. The archive is open to the public and receives from history undergraduate students until citizens looking for information about their heritage.

According to [1], the period in which the building works is termed the design life of building. The standard establishes minimum values for this period, depending on the material to be used. Therefore, the lifespan may be reduced or increased, depending on factors existing in the use of the building.

Revised Manuscript Received on June 7, 2019.

Catarina de Nazaré Pereira Pinheiro, Adriene Rodrigues Barbosa, Federal University of Pará

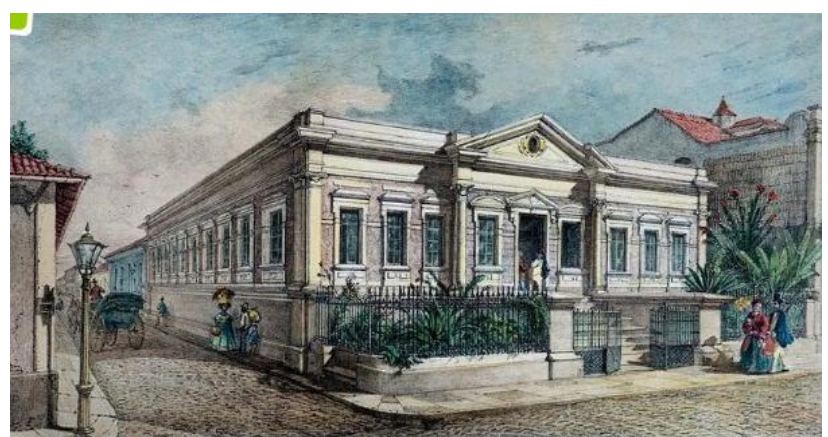

Fig. 1: Historic Building (Source: Panorama do Pará em doze vistas 1867)

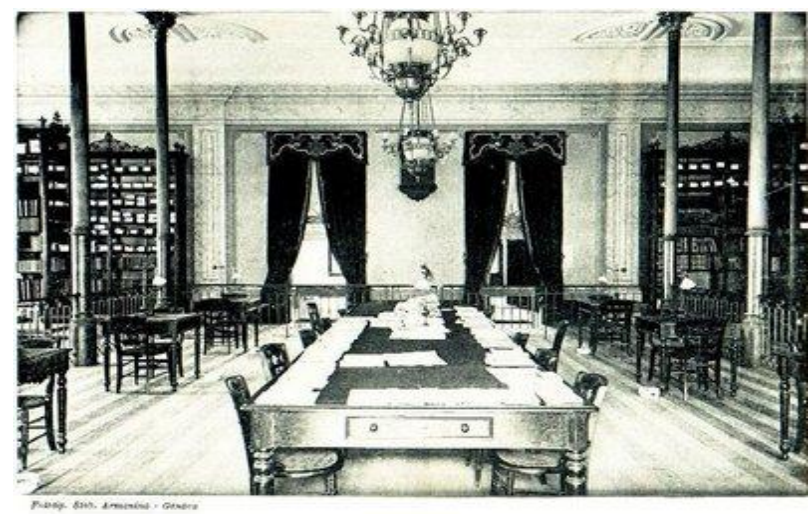

Fig. 2: Library Arquivo Público (Source: IBGE: Fotos antigas de Belém do Pará)

According to [7], the lack of maintenance of the structures, together with the low quality of the materials used in the constructions and failures in the design and execution, is one of the main reasons for the reduction of the design life of the buildings. Therefore, [2] exposes other problems caused by the reduction of the design life of building as the inconveniences caused to the user, and the high extra costs for the recovery or construction of new buildings.

Concerning the peculiarities of historic building restorations, [3] emphasizes the importance of knowledge of the entire work, since its state will determine the range and scale of the intervention. The importance and respect for edification leads to less use of more current techniques and materials [8].

Despite its historical and cultural significance, the building that shelters the archive was in a precarious situation (Fig. 3 ). In 2012, due to problems with of vulnerability of the installations, presence of humidity and lack of proper labor conditions, a group of historians mobilized a public act in favor of the protection of the documents and

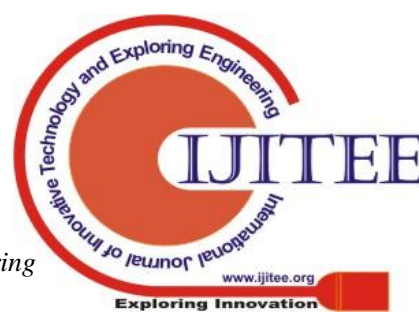


renovation of the buildings physical structure.

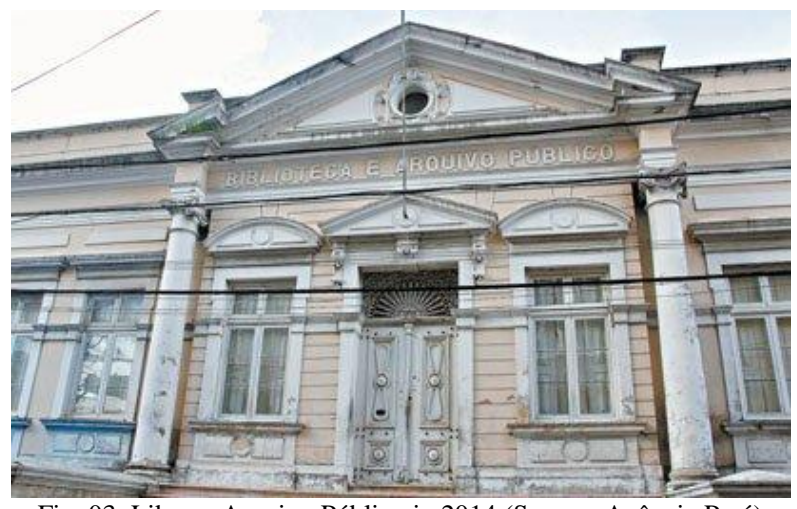

Fig. 03: Library Arquivo Público in 2014 (Source: Agência Pará)

In April of 2014, it was initiated the renovation and restoration of the construction, aiming the solution of the pathologies found. It was performed the monitoring of the work site, along with the observation of the methods used in the repair. In 24 October of 2017, occurred the inauguration of the building and the Archives were opened to be accessed by the public, recovering this heritage owned by all the society.

\section{METHODOLOGY}

The methodological procedures used in this paper were based in theoretical foundations regarding the theme, through the historical investigation concerning the Arquivo Publico, and research concerning the pathologies found in the building. Furthermore, it was performed the monitoring of the repairs execution, with the assistance of reports and photographic registers. After the conclusion of the work, it was performed an evaluation of the final results.

\section{PATHOLOGIES}

\section{A. Structural}

The main structural issues identified in the building were related to the ground floor's support beam (Fig. 4), shears, rafters and slats supporting the roof (Fig. 5), lintels for crack prevention. All these structures were made of wood, and the main cause for the pathologies were biological agents(termites).

The wooden structures were widely used during the period the building was constructed (19th century) due to the high availability in the market According to [4] the wood is a hygroscopic material, that is, it is able to absorb water either by chemical or physical reactions. Therefore, this material has many disadvantages such as the greater susceptibility to biotic agents like xylophagous insects [6]. In site, they were found termites nests inside the previously mentioned structures.

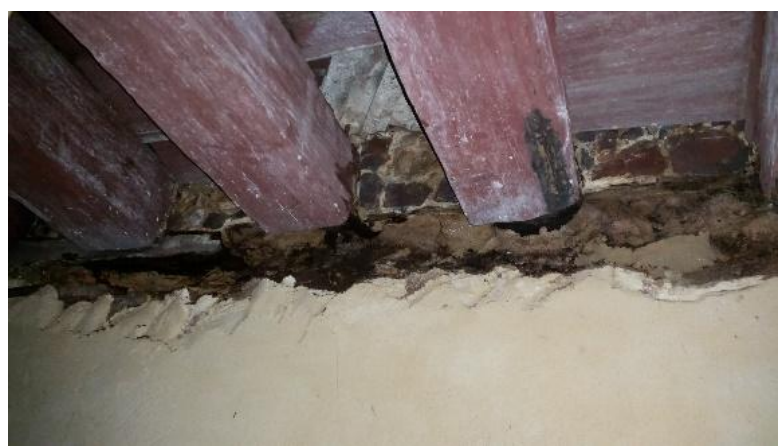

Fig. 4: Floor's support beam (Source: Author's Collection, 2014)

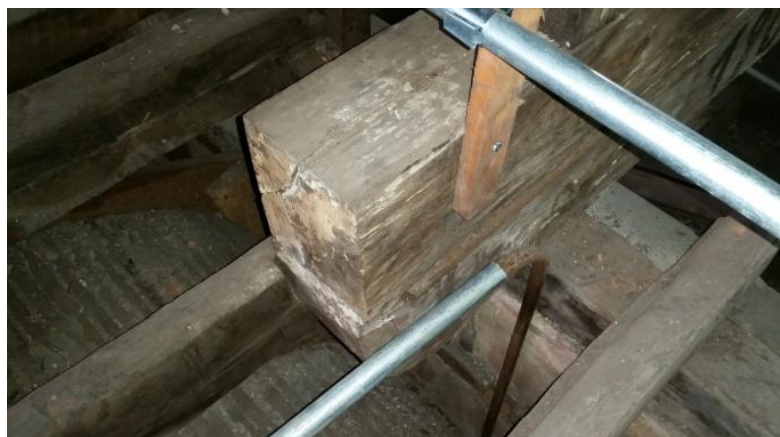

Fig. 5: Slats supporting the roof (Source: Author's Collection, 2014)

\section{B. Construction Pathologies - Walls}

In the basement level, the presence of humidity in the stone walls caused the appearance of biotic agents that harmed the working conditions and integrity of the historical documents. At the ground floor, were identified plaster detachment, appearance of stains and peeling paint due the humidity coming from a leak on the roof.

\section{Construction Pathologies - Floor}

The. korodur floor existing in the basement had many cracks and discoloration On the ground floor, the acapu and yellowheart flooring showed discoloration, dryness and some damage pieces due to the lack of maintenance. At the external area, the Portuguese pavement was uneven, generating mobility problems for those accessing the building.

\section{Construction Pathologies - Ceiling}

The wooden ceiling on the ground floor was damaged due the presence of humidity coming from the leaks on the roof (Fig. 6). The plaster ceiling at the main room was also damaged due to water infiltration.

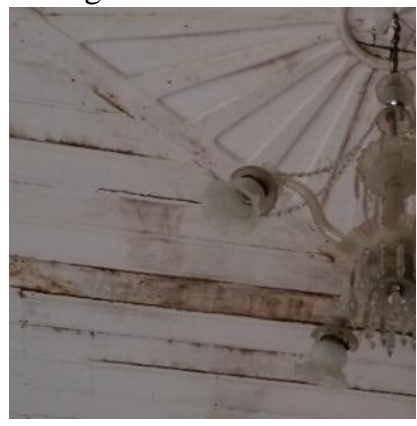

Fig. 6: Ceiling (Source: Author's Collection, 2014) 


\section{E. Construction Pathologies - Door and Window Frames Ceiling}

Most of door and window frames of the building had pathologies related to abiotic and biotic agents, presence of humidity and termite proliferation (Fig. 7). Moreover, most of the hardware was damaged.

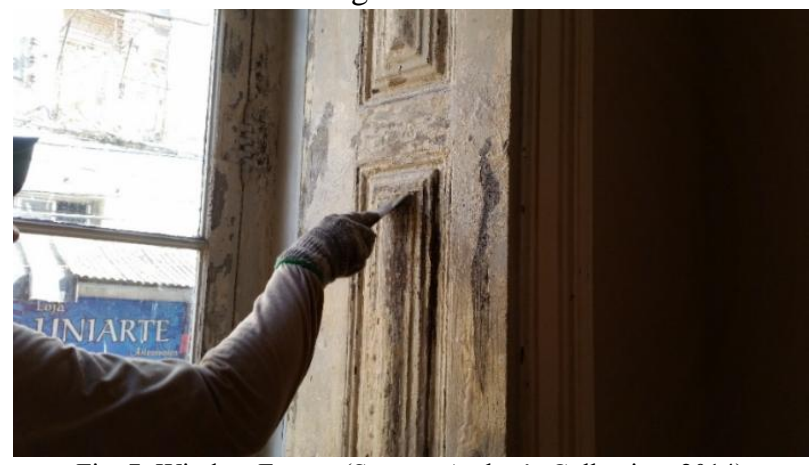

Fig. 7: Window Frame (Source: Author's Collection, 2014)

\section{F. Construction Pathologies - Roof}

The building's roof showed precarious conditions due to damage roof tiles, absence of waterproof cover and gutter (Fig. 8). These pathologies increased the occurrence of infiltrations inside the building, being the main cause for many other pathologies.

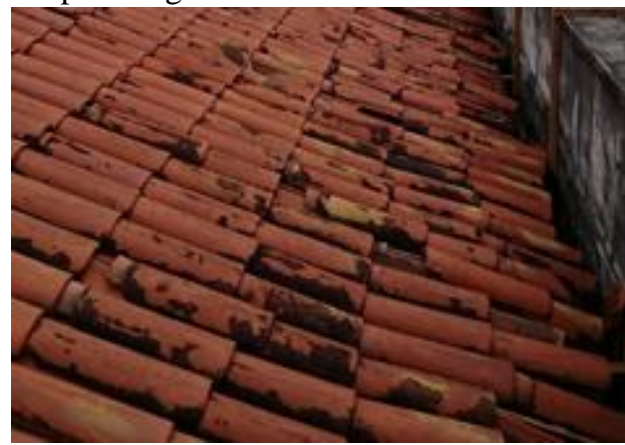

Fig. 8: Roof (Source: Author's Collection,2014)

\section{G. Construction Pathologies - Building}

\section{Installations}

The electrical installations were in a bad conservation state (Fig. 9), threatening the collection in the building due the increased risk of fire. This condition was worsened due the inefficiency of the firefighting system. Concerning the hydraulic installations, the absence of a drainage system stands out. The cooling system was ineffective in the basement, which harmed the proper conditioning of the documents.

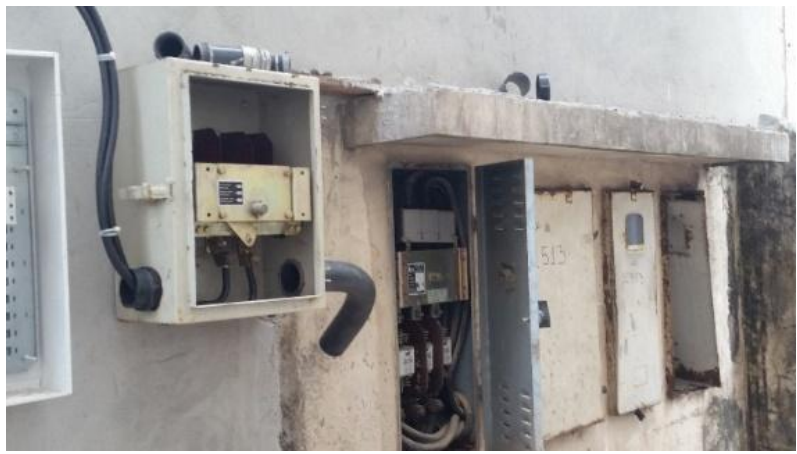

Fig. 9: Electrical installations (Source: Author's Collection, 2014)

\section{H. Construction Pathologies - Pieces in need of Restoration Building Installations}

Among the issues found, it is important to mention the pieces that need repair due the originality and historical relevance of these items or scarcity of the material in the market. Examples of these pathologies are damages found on the original architectural pieces components of the facade, the stair at the main entrance and sidewalk in lioz limestone, the marble floor on the entrance hall.

\section{RENOVATION AND RESTORATION}

\section{A. Structural}

To solve the pathologies found in the support beams, shears, rafters and slats supporting the roof and lintels, it was performed a termite termination, replacement of the compromised pieces and reinforcement of the damaged beams and shears with metal sheets. (Fig. 10 and 11)

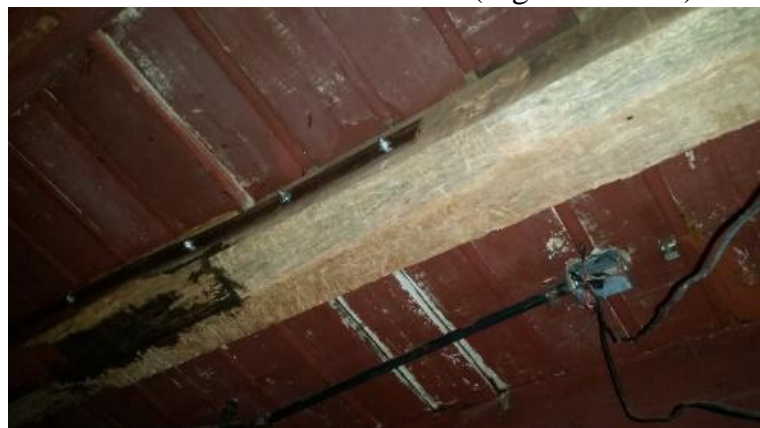

Fig. 10: Support beams (Source: Author's Collection, 2014)

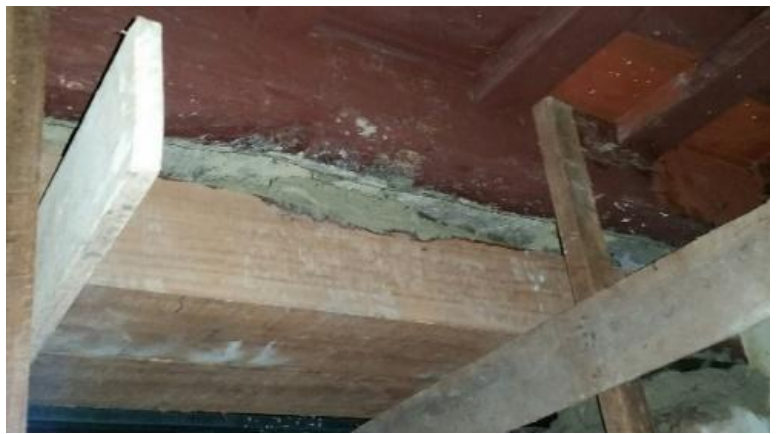

Fig. 11: Support beams (Source: Author's Collection, 2014)

\section{B. Construction Pathologies - Walls}

The continuity of the constructive techniques was necessary to maintain the historical heritage. To evaluate the best restoration method, it was developed a diagnosis through the sampling of the original material and subsequent laboratory analysis. This procedure was used for both internal and external plaster. To select the paint, the method was the prospection, removing all the layers of wall paint to find the original layer. (Fig. 12)

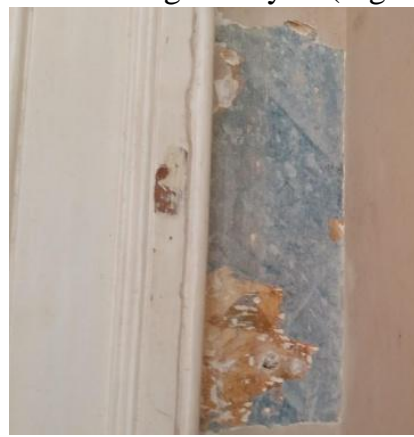


Fig. 12: Layers of wall (Source: Author's Collection, 2014)

After evaluation of the ideal mix design of the plaster for the stone base, the walls of the basement level were plastered using lime, cement and clay, approaching the executive process used in the historical period of the construction, finishing with sealer to maintain the rustic original appearance (Fig. 13). On the ground floor, the damaged original plaster was removed and a new plaster was executed, removing the superficial layer of paint, puttying and painting the walls. (Fig. 14)

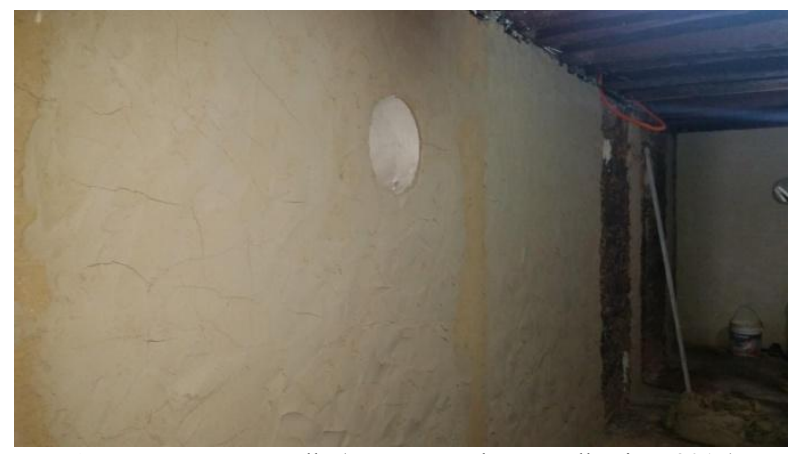

Fig. 13: Basement walls (Source: Author's Collection, 2015)

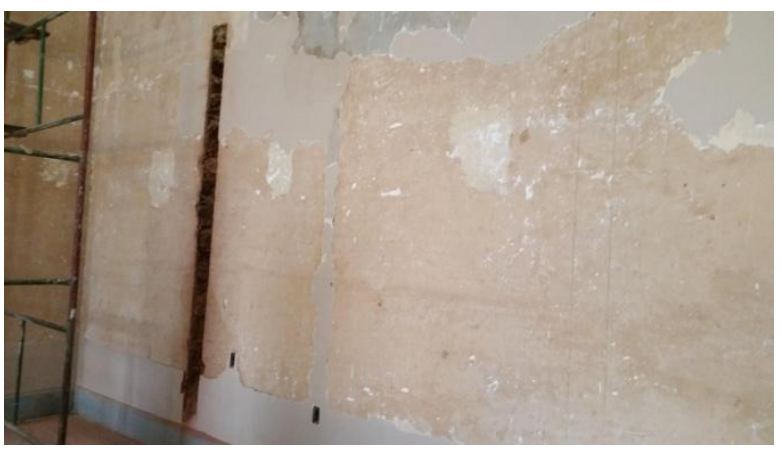

Fig. 14: Walls (Source: Author's Collection, 2015)

\section{Construction Pathologies - Floor}

Due to the high compromising of the korodur floor, it was applied a new layer of the material mixed with cement and water. After the curing process, the floor was polished, and a floor resin was applied to facilitate the maintenance. (Fig. 15 and 16).

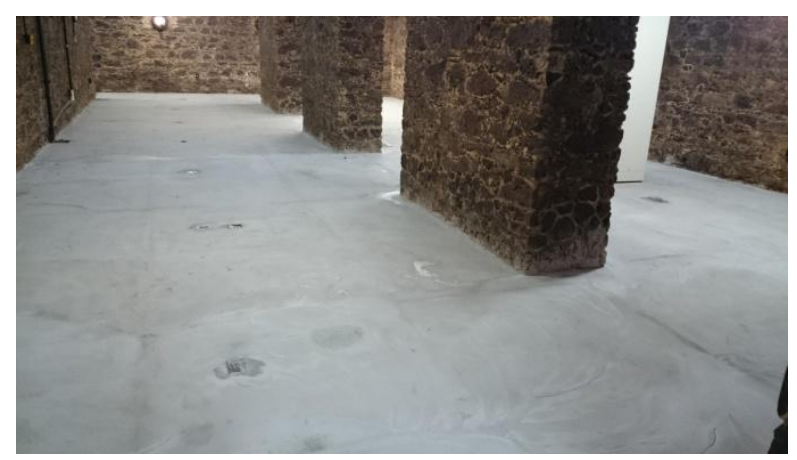

Fig. 15: Korodur floor (Source: Author’s Collection, 2014)

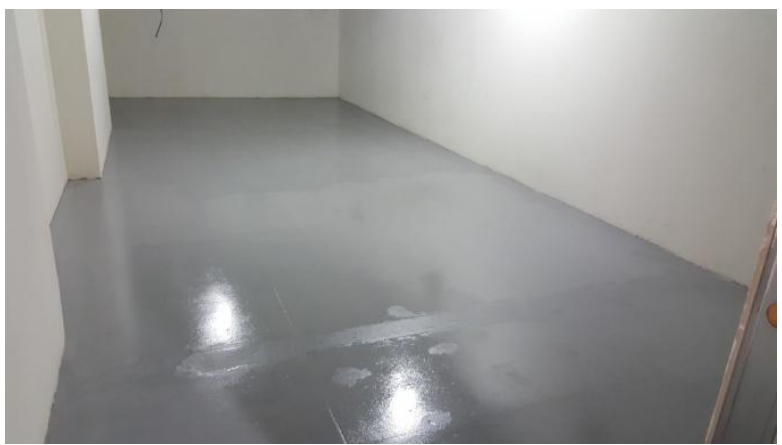

Fig. 16: Application of floor resin (Source: Author's Collection, 2016)

Concerning the wooden floors, the technique used was the replacement of the deteriorated pieces, application of abrasive papers, caulking, polishing, finishing with a layer of wood varnish. The leveling of the floor in Portuguese stone was performed in the external area through the removal and subsequent cleaning of the pieces, compaction of the sand layer and replacement of the clean pieces (Fig. 17 and 18).

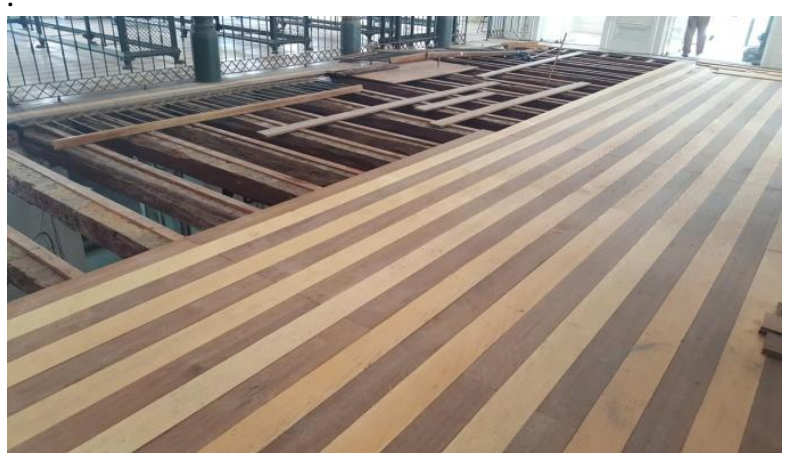

Fig. 17: Wood floor (Source: Author’s Collection, 2016)

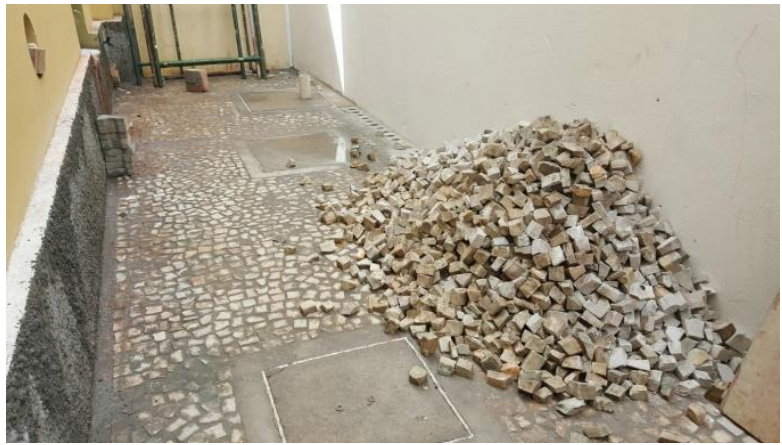

Fig. 18: Floor in Portuguese stone (Source: Author's Collection, 2016)

\section{Construction Pathologies - Ceiling}

The damaged pieces of the ground floor wooden ceiling were replaced, grinded and repainted. The plaster ceiling had its damage parts repaired and the frames were rebuilt. (Fig. 19) 


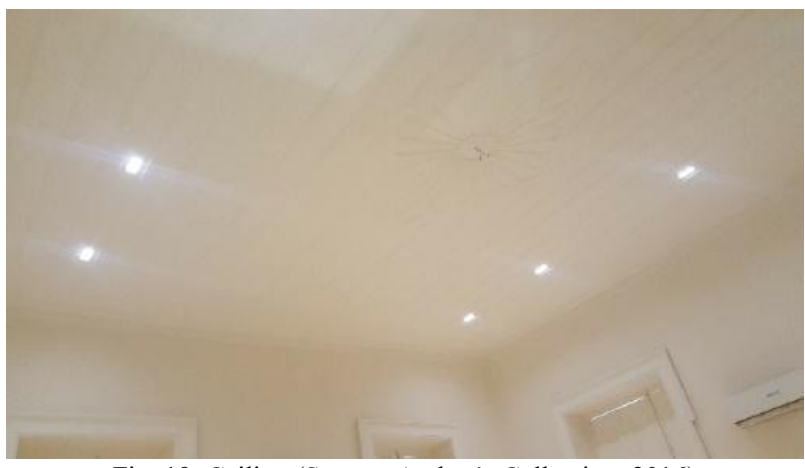

Fig. 19: Ceiling (Source: Author's Collection, 2016)

\section{E. Construction Pathologies - Door and Window Frames}

To solve the pathologies encountered in the door and window frames, it as performed a termite termination, replacement of the damaged pieces, removal of the painting with spatulas and chemical products, puttying, grinding and painting of the frames.

(Fig. 20)

Moreover, the hardware was replaced to match the original design of the building, according to architectural studied made.

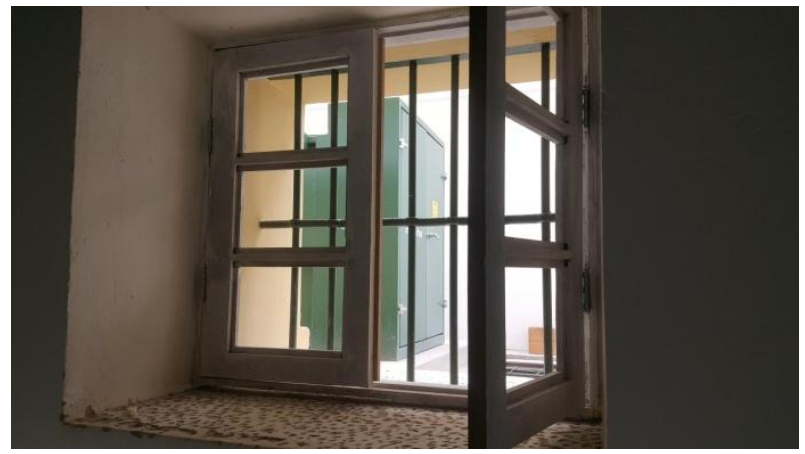

Fig. 20: Restoration of windows (Source: Author's Collection, 2015)

\section{F. Construction Pathologies - Roof}

The pathologies found on the roof of the building were fixed through the application of an asphaltic membrane (Fig. 21 ), replacement of damaged titles and cleansing of the roof pieces. Furthermore, it was constructed a metal gutter to channel the rainwater. (Fig. 22)

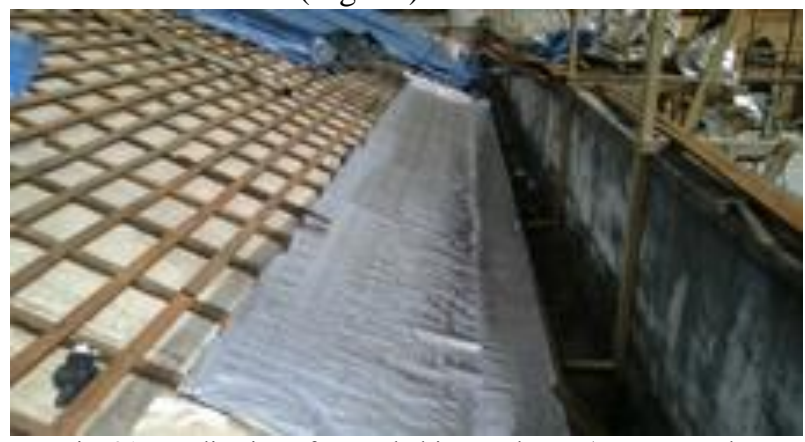

Fig. 21: Application of an asphaltic membrane (Source: Author's Collection, 2014)

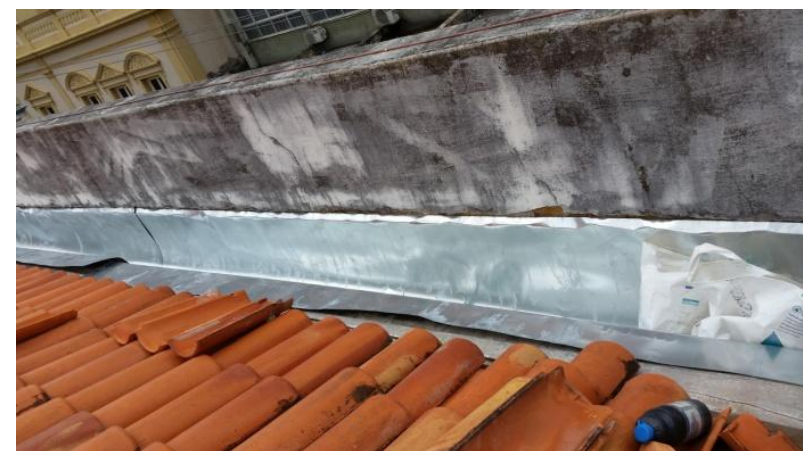

Fig. 22: Metal gutter (Source: Author's Collection, 2015)

\section{G. Building Installations}

The electrical installations were replaced and adjusted to today's pattern. In addition, it was created a system to prevent damages caused by electrical discharges (Fig. 23). The firefighting system and cooling system were adjusted. A drainage system was built, and the hydraulic installations were realigned to match the alterations made in the original project. (Fig. 24)

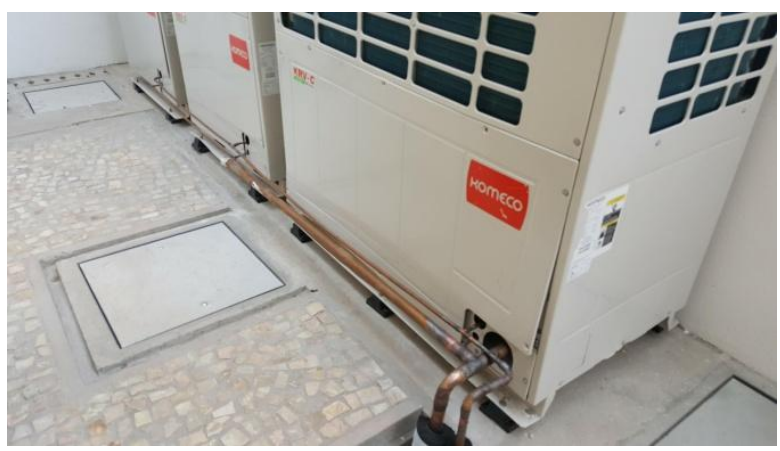

Fig. 23: Electrical Buildings (Source: Author's Collection, 2016)

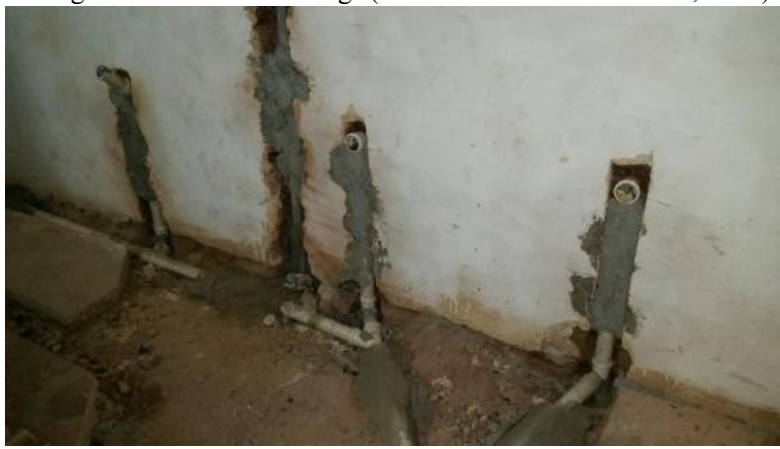

Fig. 24: Hidraulica Buildings (Source: Author's Collection, 2016)

\section{H. Construction Pathologies - Pieces in need of Restoration}

The building's facade had its frameworks rebuilt with suitable mortar and the ornament pieces were remade utilizing silicon molds similar to the originals. Furthermore, the facade was painted using the original colors obtained during the prospection process. (Fig. 25) 


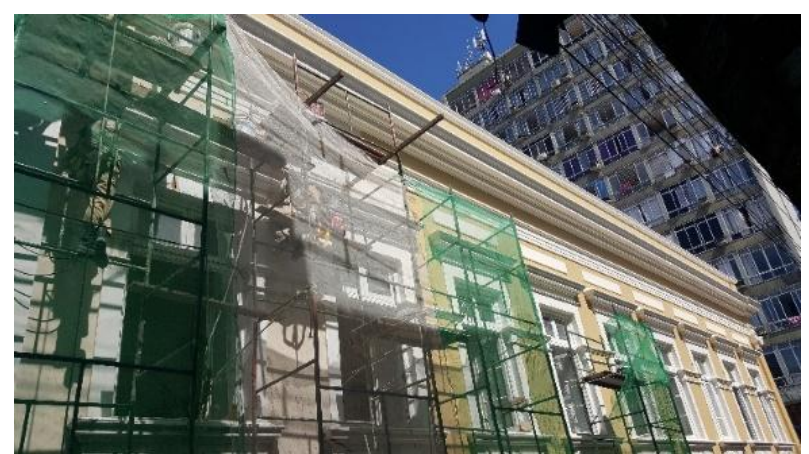

Fig. 25: Building's facade (Source: Author's Collection, 2016)

The access ladder in lioz stone was repaired using material like the original, polishing and resin application. The same process was performed on the marble floor on the main hall, using the adequate materials. (Fig. 26 and 27)

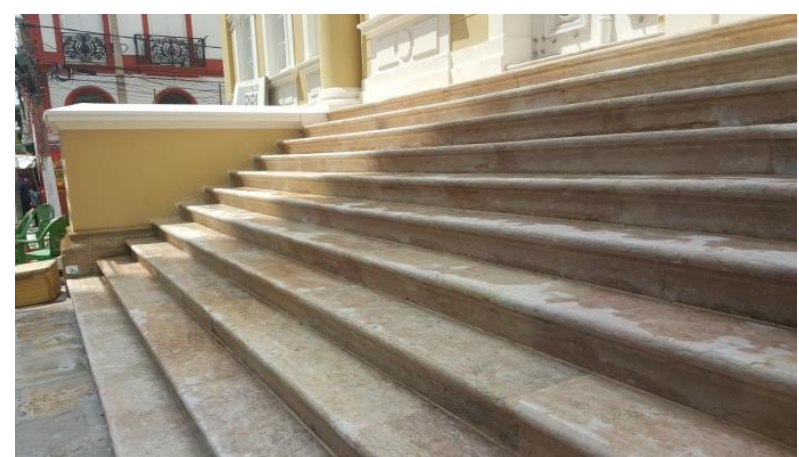

Fig. 26: Ladder in lioz (Source: Author's Collection, 2016)

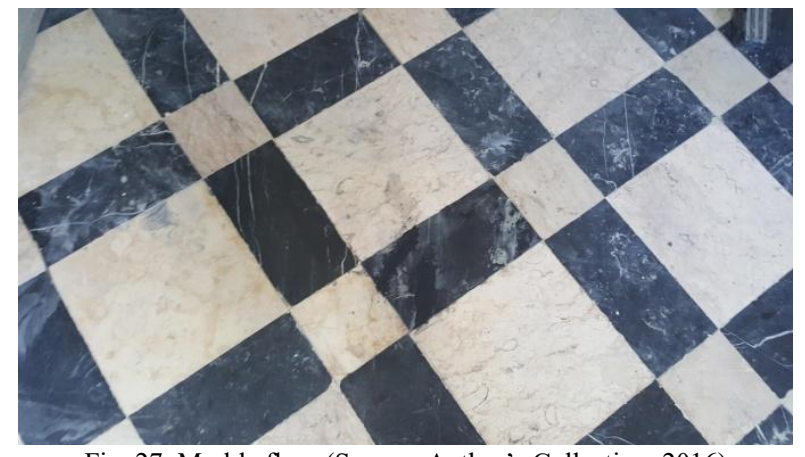

Fig. 27: Marble floor (Source: Author's Collection, 2016)

\section{Architectural Changes}

Aiming the improvement of the accessibility to the building, some changes on the original architectural project were made. The permutation of restrooms, kitchen and DML to improve the comfort of visitors, the construction of a access ramp (Fig. 28) and installation of an elevator to people with special needs are the highlighted alterations made.

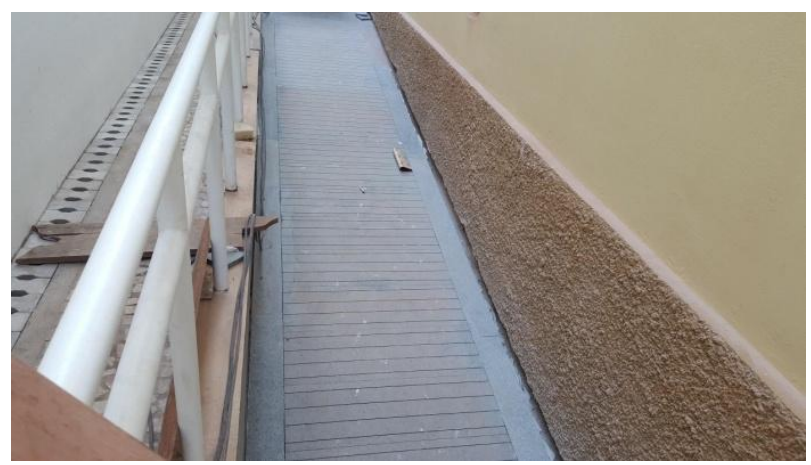

Fig. 28: Access ramp (Source: Author's Collection, 2016)

Due to the process of permutation of rooms, alterations on the structural system were necessary. New foundations, metal beams and pillars, concrete slabs (Fig. 29) and metal ladder were executed, the hydro-sanitary and electrical systems were realigned and new installations were finished. (Figuras 30).

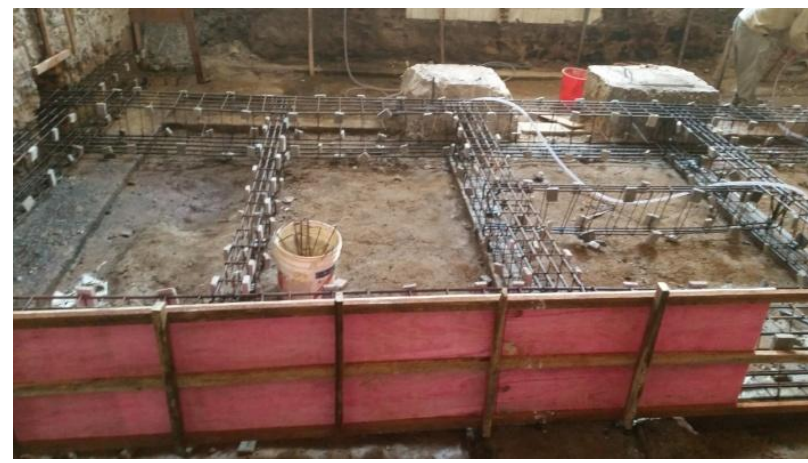

Fig. 29: Foundations, metal beams and pillars, concrete slab (Source: Author's Collection, 2016)

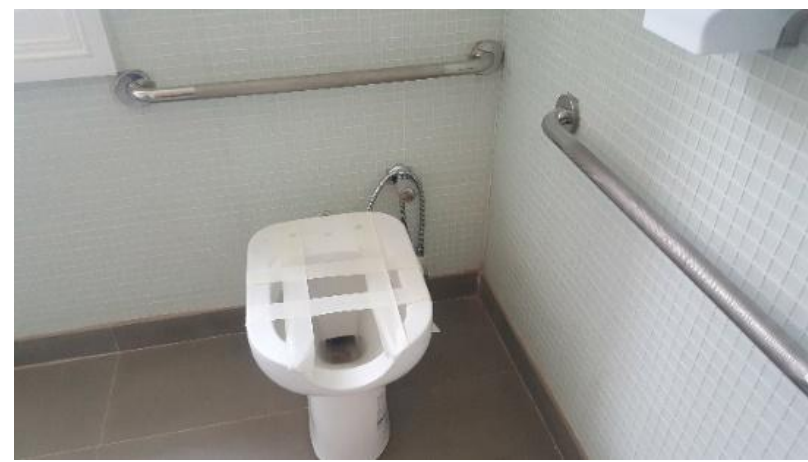

Fig.30: Hydro-Sanitary installations: Ba (Source: Author's Collection, 2016)

\section{RESULTS}

After the construction work ended, it was performed and released to the public a photographic record of the reform and restoration attained results (Fig. 31 and 32). The building was reopened to the public in October of 2017 and operates regularly nowadays.

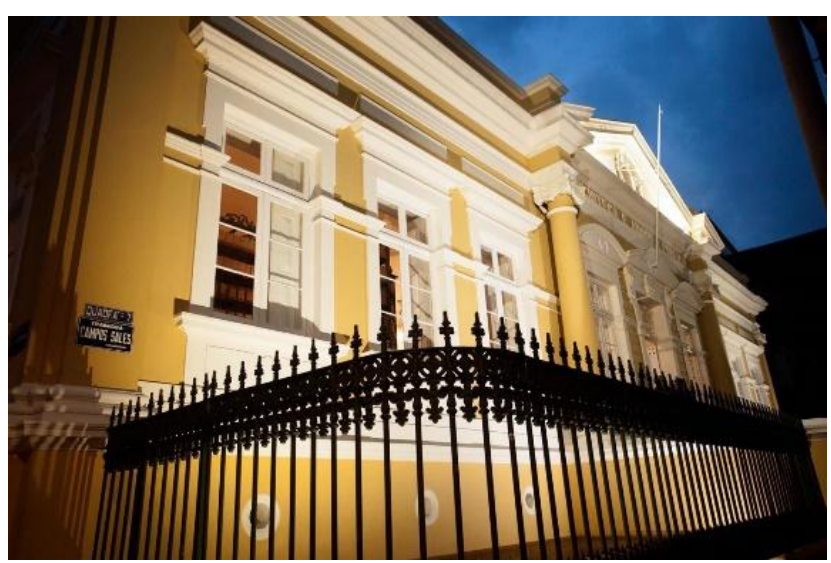

Fig. 35: Library Arquivo Público (Source: Press Release 2017)

Published By

Blue Eyes Intelligence Engineering \& Sciences Publication

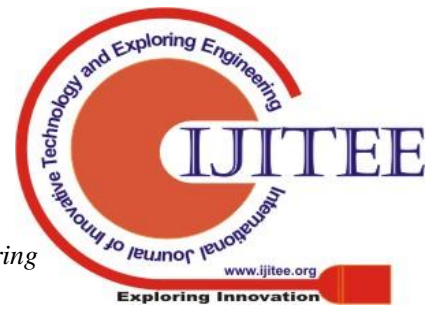




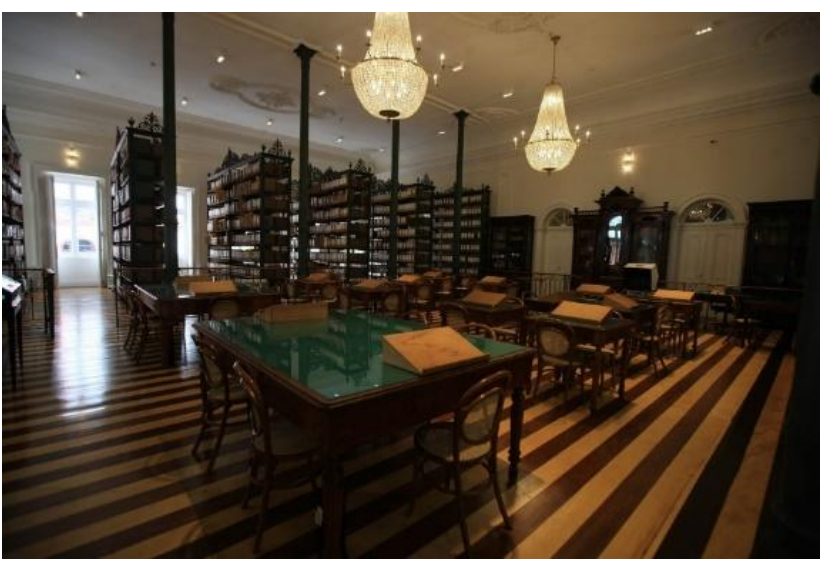

Fig. 32: Restoration of ground floor (Source: Press Release 2017)

\section{CONCLUSIONS}

The monitoring of the construction work allowed the evaluation of the executive procedures and they were considered efficient to reach the maintenance of the original pattern of the historic building and improve the working conditions for its employees, guaranteeing the comfort of visitors and correct conditioning of the importanthistoric documents restored in site.

The alterations also guarantee the integrity of the documents and enabled the process of modernization of the archives through the scanning of the collection, which was previously prevented due the inefficient of the buildings installations. This way, Amazon's history and culture can be preserved and disseminated in a general scope.

Even though the initial deadline stipulated was one year, the work took three years to be finished, due contractual divergences that caused temporary stoppage. Despite the delays, the procedures were performed according to the expected standards, reaching the result expected by the community. After the construction work ended, it was performed and released to the public a photographic record of the reform and restoration attained results. The building was reopened to the public in October of 2017 and operates regularly nowadays.

\section{REFERENCES}

1. ABNT, Associação Brasileira de Normas Técnicas. NBR 15575 Edificações habitacionais - Desempenho. 2013.

2. ABNT, Associação Brasileira de Normas Técnicas. NBR 5674 Manutenção de Edificações - Requisitos para o sistema de gestão de manutenção. 2012

3. ARENDT, C. O. (1997) Exaustivo Caminho da Recuperação. Congresso Ibero Americano de Patologia das Construções, Porto Alegre: CPGEC/UFRGS, Porto Alegre.

4. BERTOLINI, L. Materiais de Construção: patologia, reabilitação, prevenção; tradução Leda Maria Marques Dias Beck. São Paulo: Oficina de Textos, 2010

5. CUNHA, Maria Clementina Pereira. (Org.) O Direito à Memória: patrimônio histórico e cidadania. São Paulo: Departamento do Patrimônio Histórico, 1992, p. 25.

6. CARRASCO, E. V. M., "Apostila: Estruturas Usuais de Madeiras", Dpto de Estruturas,UFMG, 2009

7. POSSA, E.; Demoliner, C. A. (2013) Desempenho, durabilidade e vida útil das edificações: abordagem geral.

8. PERES, R. M. (2001) Levantamento e Identificação de Manifestações Patológicas em Prédio Histórico - Um estudo de caso. Dissertação (Mestrado em Engenharia Civil) - programa de Pós-Graduação em Engenharia Civil - UFRGS, Porto Alegre. 142 p.
9. TOMAZ, Paulo Cesar. A preservação do Patrimônio Cultural e sua trajetória no Brasil. São Paulo: Fênix - Revista de História e Estudos Culturais Maio/ Junho/ Julho/ Agosto de 2010 v. 7 year VII no 2.

10. VIANA, A. O. V. N. A biblioteca e arquivo público (do pará): resumo histórico. Revista de Biblioteconomia de Brasília, v. 3, n. 1, p. $85-$ 102, 1975. Available in: <http://www.brapci.inf.br/v/a/3697>. Access in: 15 Jan. 2018.

\section{AUTHORS PROFILE}

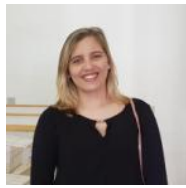

Catarina PinheiroI'm graduated in Civil Engineering from the Federal University of Pará and currently graduate student in structures and materials from the Federal University of Rio de Janeiro. Professionally, have experience with renovation and restoration, construction management, and teaching. In the academic field, I worked on research lines of renovation and restoration, optimization, concrete structures, structural modeling and currently viscoelasticity and meshless method.

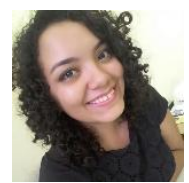

Adriene Barbosa I am an undergrad student of Civi Engineering at Federal University of Pará, with a minor in Sustainable Infrastructure from University of California, San Diego. 